\title{
THE COLONIAL OFFICE AND EDUCATIONAL POLICY IN BRITISH NORTH AMERICA AND AUSTRALIA BEFORE 1850
}

\author{
Bernard Hyams
}

Little has been written in recent times about the early British Colonial Office with respect either to policy or to processes. Helen Taft Manning's seminal work on British colonial government (1772-1820) was first published in 1933 with a reprint in 1966, while Paul Kraplund's book on James Stephen and the British colonial system (1813-1847) dates back to $1953 .^{2}$ Morrell's account of British colonial policy during the ministries of Sir Robert Peel and Lord John Russell (1841-1852) was published in $1966^{3}{ }^{3}$ Other useful works such as those by Young ${ }^{4}$ and Ward ${ }^{5}$ similarly first appeared some considerable time ago. A number of worthwhile publications have appeared on the scene in more recent times but these attend to the later nineteenth and twentieth centuries or to specific countries. For the reader in quest of specialized treatment of education in the Empire for the first half of the last century, there is virually nothing available in consolidated form.

Yet there can be little doubt that religion combined with education to present an important issue for the Colonial Office in the post-American War era. In both North America and Australia, especially in the $1830 \mathrm{~s}$, it was having to deal with the vexed and intertwined colonial issue of schooling, state, and church; indeed the two aspects were linked in a controversy over clergy reserves of land in Upper Canada which, it is claimed, contributed to the 1837 rebellion in that province. ${ }^{6}$ Individual publications have, in their respective accounts of educational development in the two regions, touched upon the attitude of the Imperial authority on the matter. ${ }^{7}$ But the reader is nevertheless still faced with one largely unanswered question - whether there was a readily discernible Colonial Office policy or even a consistent official attitude on education in the earlier nineteenth-century phases of imperial development. Here were two areas of Empire, both overwhelmingly European in their standard culture, both multi-denominational in religion, both vigorously pursuing the education of local youth within those important contexts, yet experiencing sufficient differences of degree in these aspects to offer comparisons useful not only as ends in themselves but also as a dimension for establishing the existence of a formative thrust of colonial educational policy. While the intensity of the issues involving state, church, and education reached a peak in both regions in the 1830 s, some attention must also be given to earlier years which heralded the problems, and to the following decade, in which the repercussions were still being felt. 
In the quest to identify such an attitude or policy, the conclusions drawn by Helen Taft Manning from her extensive document search are pertinent. Concerning the period before 1830 , she found that the dispatches signed by the Secretary of State for the Colonies contain most of the official pronouncements on colonial policy. ${ }^{8}$ There is little reason to suppose that this situation did not continue into the 1830 s, the period of special focus in this article, which is therefore based largely on an examination of dispatches from the Secretary of State to the various govemors of the North American and Australian colonies (particularly New South Wales). Much has been said and much made of the influence of James Stephen before as well as during his term of office as Under-Secretary, and it is not proposed to dispute those claims. ${ }^{9}$ It should not be overlooked, however, that the dispatches sent to the colonial governors were either dictated by the Secretary of State himself or prepared under his instructions by the Under-Secretary; there might even be the odd occasion, in matters educational, when the contrary view of the politician was maintained. ${ }^{10}$ Some of the ministerial heads of the office were more knowledgeable and more vigorous than others; some, such as Lord Goderich, pursued emphatic colonial policies and presided over what seemed to be changes in policy. It might also be expected that successive Secretaries of State projected into their handling of affairs the broad thrust of either Whig or Tory sentiment rather than mere personal predilection or idiosyncrasy. We are therefore left to seek out a thread of consistency and continuity which might constitute either a developed or at least an embryonic policy on education within the British Colonial Office.

It has already been established that the nucleus of a true Colonial office dates from Lord Bathurst's entrance in 1812 and that he and Goulburn strongly fostered its separate identity. ${ }^{11}$ This duo extended the early departmental preoccupation with slavery into other issues of concern such as emigration, currency, defence, and, significantly for this exercise, religion. ${ }^{12}$ Religion was in a strong sense deemed at that time to be inseparable from education. Bathurst's instruction in 1819 to John Thomas Bigge on his Commission of Enquiry into New South Wales was unequivocal on this point:

You will also turn your attention to the possibility of diffusing throughout the colony adequate means of Education and Religious instruction, bearing always in mind in your suggestions that these two Branches ought in all cases to be inseparably connected. ${ }^{13}$

This view was readily maintained since education was conceived of not only as an instrument of literacy but also as a vehicle for spiritual values: support for religious activities generally took the form of promotion of instruction in religious beliefs and practices. And there were numerous signs of Colonial Office solicitude for the promotion of religious education in the expanding Empire of the early nineteenth century. The "deplorable condition of religion and education" in Prince Edward Island was sufficient to persuade Bathurst to seek 
additional funds from the Parliamentary Estimates in Britain to help remedy the situation; and he was more than willing to allow Roman Catholic priests to be paid allowances to attend to their flocks in the penal establishments in New South Wales, "so long as they shall continue to conduct themselves with propriety." Numerous other dispatches for North America in the first few decades of the century, including those for the largely French and Catholic Lower Canada, abound with examples of official approval for services and salaries for teachers to be appointed to a certain location.

In terms of the policy of aid to education there were two major modes of assistance from Britain. One was the approval of legislation to set aside land as the basis of income for the church to promote its religious and educational activities. This had occurred, for instance, in Nova Scotia and Newfoundland, but the best-known example was the provision in the Canada Constitution Act of 1791 which set aside one-seventh of Crown land in Upper Canada in order to help fund the support and maintenance of the Protestant clergy. Given the strong contemporary identification of education with religion, this particular aspect of the Act may be regarded as a form of encouragement for education as well. In 1825 , a similar system was applied to New South Wales under the Church and Schools Corporation for the maintenance of churches and schools in that colony. The other major form of support from Britain was the practice of granting a royal charter for the establishment of particular institutions of higher education. These colleges appearing in North America often formed the basis of future universities, but were also intended as important instruments of training for the clergy.

In its concern to advance the diffusion of religion and education, the Colonial Office was influenced by a number of considerations. One of these was the question of finance, embodied in the insistence that colonial educational ventures should not impose a drain on the Treasury. This firmly and consistently held view was to manifest itself in the moves to terminate the reserves of land for church and clergy and in exhortations to colonial authorities to proceed cautiously-and with local funding--in their initiatives to establish colleges. Another guiding principle followed by successive Secretaries of State for the Colonies and their Under-Secretaries was the legal/constitutional consideration. An important issue in this matter was the position of the established church. The issue manifested itself when Catholics, especially in Lower Canada, pressed for forms of state assistance in educational development and were answered with reference to the Elizabethan Act of Supremacy. Elsewhere in the North American colonies the debate focused on whether the provisions for clergy, church, or school lands had legally given exclusive rights to the Church of England over the claims of other Protestant denominations. In the matter of higher education the argument revolved around the standing of royal charters initially granted only to Anglican institutions.

In a number of cases involving matters of educational dispute both constitutional and political factors came into play. No Australian colony was to receive any form of elective legislature until 1842, but the North American colonies had 
popular assemblies operating quite vigorously by the 1830s. It was often the case that the Colonial Office was faced with resistance to the wishes of these bodies by intractable legislative councils, not popularly elected and representing the local social and denominational elite. Where disputes between the two branches of the legislature arose over education, the most common response of the Colonial Office was to evince a measure of sympathy for the popular cause but to emphasize the constitutional restraints (for example, especially under the 1791 Act) upon its interference in disputes between the parliamentary bodies.

By the 1820 s, the Colonial Office was having to respond to a changing demographic situation in North America and in Australia. In parts of the former, an influx of United Empire Loyalists, Post-Loyalists, and other immigrants had increased the demand for popular education and had exacerbated fears of American republicanism; in the Australian colonies, namely New South Wales and Van Diemen's Land, the transition from a penal society to one dominated by emancipated convicts and free immigrants similarly led to an increased emphasis on providing schooling at the elementary level. In both places the local colonial authorities held that these educational thrusts would best be exercised under the auspices of the Church of England. In Upper Canada a move to eclipse the non-denominational schools established under the Act of 1816 enjoyed the backing of Governor Maitland and a leading public figure, the Reverend John Strachan, and materialized as an attempt by Maitland to establish monitorial schools in the pattem of the Church of England's "National Schools" in Britain. With Strachan appointed as president of a General Board of Education for Upper Canada, the Anglican Church was virtually handed control of popular education in the colony. ${ }^{15}$ In the Australian case, official support for the Church of England seemed to proceed more automatically. In 1823 the British Government had accepted the advice of Anglican clergyman Thomas Hobbes Scott, formerly secretary of an official enquiry into New South Wales several years earlier. One of the accepted recommendations of the enquiry was to establish in New South Wales clergy reserves of land for the support of religion and education in the colony. Although this proposal was strongly reminiscent of the provision of the 1791 Constitutional Act which had set aside one-seventh of Crown land in Upper Canada, it did not generate the same degree of controversy. The 1791 measure set aside lands "for the Support and Maintenance of a Protestant Clergy," an expression which was deemed for many years after to mean an Anglican clergy and was consequently subjected to fierce challenge. ${ }^{16}$

The Colonial Office has been charged with anomalous or inconsistent behaviour on this issue of land reserves. Secretary of State Bathurst, we are reminded, actively supported a system of privilege for the Church of England in Austral ia during a period when that privilege had been under growing attack from other denominations in Canada and when Bathurst, Tory though he was, had conceded that the favours might have to be extended there-at least to the Presbyterians. ${ }^{17}$ Did his lordship really forget about the problem in Canada when dealing with the question in New South Wales? The contention is not strongly 
credible. The Colonial Office was well aware of the extent of denominational dissension in Canada and of the difficulty of maintaining a de facto Anglican church establishment in a region where its adherents lacked a majority; the resistance in Upper Canada to church privilege was clearly registered by the Secretary of State, prior to the decision on Australia, when having to deal with conflicting interpretations of the provisions of the clergy reserves. ${ }^{18}$ Nor could Whitehall have been unaware of local political alignments which coincided with denominational differences. In Upper Canada, for instance, the Anglican, conservative oligarchy, known as the "Family Compact," exerted its influence through the Executive and Legislative Councils as well as through the persons of Strachan and Governor Maitland. The elected Legislative Assembly, on the other hand, offered a locus of popular resistance to exclusiveness, especially when the Reformers were in the ascendancy. In the 1820 s and 1830s, New South Wales was still without a representative legislature but a vigorous clamour was being heard from emancipists (ex-convicts) and free settlers for liberal changes to reduce the power of both the governor and the ruling elite-the "exclusives"-as well as to deny the pretensions of the Church of England.

Given these general similarities, it might be argued that the Colonial Office could, therefore, have averted a Canadian-type replication in Australia of inevitably unpopular favours to the Church of England. Castigation of the British authority in these terms, however, overlooks a number of principles on which it operated. One such principle was a sensitivity to those real differences which it perceived among the general similarities between colonies. Glenelg, in 1837, very strongly made the point on demography which Bathurst in 1823 could not have failed to notice. Speaking of a recently adopted Australian provision for churches and support for ministers, Glenelg argued:

The circumstances of the Australian Colonies differ so widely from those of Canada that it would be plainly impossible to transfer to the latter country the entire system which has been adopted with success in the former. 19

Mindful of the strength of nonconformist denominations in Upper Canada, especially the Methodists, he reminded North American governors that whereas in Australia a very high proportion of colonists followed the Churches of England, Scotland, or Rome, the Canadian provinces had large communities belonging to other Christian groups. ${ }^{20}$

There were relatively subtle legal differences as well. In New South Wales the matter at first seemed straightforward: the proceeds of land sales were to have supported the Church of England and its schools and schoolmasters. ${ }^{21}$ But when it came to winding up the corporation which had administered those lands, some dispute arose. Archdeacon Broughton contended strongly that the British Orderin-Council, which in 1833 vested the lands in the Crown, did so for the maintenance of Anglican religion and education. The Colonial Secretary, however, 
upheld the counterview of the Governor that the Crown had the right to apply the proceeds from the lands for the promotion of religion and education without reference to any particular church. ${ }^{22}$ The conclusion was reached without recourse to legal opinion. In the North American case, however, there was a need to discriminate between competing legal claims, specifically to determine whether the conferring legislation had in fact given exclusive rights to the Church of England. In Upper Canada, the phrase detailing support for "a Protestant Clergy" was the subject of disputed interpretation, with the term "Protestant" held variously to mean all Protestant denominations or, narrowly, only the Church of England. Even the restricted version was debated in terms of whether it was also meant to include the other established British church, the Church of Scotland. In pursuit of clarification on the matter, the Colonial Office had sought, and gained in 1819 , an opinion from the law officers of the Crown. The legal view thus given was that the Church of Scotland had a right to participate in the proceeds of the clergy reserves, a judgement of which Lord Glenelg had to remind Governor Arthur in 1837, contradicting the latter's expressed doubts on the Church of Scotland's claim. ${ }^{23}$

Moreover, what was determined for the colony of Upper Canada did not necessarily automatically apply elsewhere. Anglican claims on alienation of unsettled lands in New Brunswick did not find a ready answer from Glenelg, who moved to seek legal opinion on the request of the Archdeacon of New Brunswick for land grants to the Society for Propagation of the Gospel. Anticipating the possibility of a judgement which might award discriminating power to the government, the Secretary of State instructed the governor to consult his Executive Council on the best course to adopt in responding to the request for land. ${ }^{24}$ The Anglican claim for the whole of the land set aside for education in Nova Scotia drew a different response from the Office two years later when it disallowed local legislation on the matter and urged a commission of enquiry. ${ }^{25}$ Legal opinion was also sought for the dispute in Prince Edward Island, with the result that Britain chose to make a fine distinction between support for religion and support for education, exclusive Anglican rights being countenanced for the former but not the latter. In strictly adhering to the new legal clarification, Glenelg found himself in direct opposition to the view of the local legislature. ${ }^{26}$ In making these determinations the Colonial Office had perceived niceties of difference in the legal situation in the respective colonies: what may have seemed correct procedure for one was not necessarily appropriate for the other. Lord John Russell did in fact make the specific point that the judicial interpretation given to the situation in Upper Canada could not cover the case in Prince Edward Island, for the statute in question for the one province had no application to the other. $^{27}$

Financial considerations were at least as prominent as legal factors in shaping the official attitude towards education in North American and Australian colonies. It has been noted that Goderich had made his mark in Britain during the Liverpool Ministry as an advocate of mercantile and monetary reform and 
that Wakefieldian principles of colonial reform and practice shaped his attitude towards the waste lands issue in the $1830 \mathrm{~s}^{28}$ In one of his 1831 dispatches to Governor Colbome of Upper Canada, he lamented that the system of reserving waste land for a public purpose had failed and that in the forty years of its operation the income from the clergy reserves had not equalled its expenses of managemeat. In both Australia and Canada, experience had demonstrated that "where so" much land remained unappropriated it could only profitably be occupied by those who had the stimulus of personal and permanent interest." 29 This view took hold of official thinking for other times and places; in the case of New Brunswick, subjected to somewhat less rancour over church and schools, the financial failure of the system in Upper Canada was quoted by Lord Aberdeen in urging disposal of church and school lands and use of the proceeds for Christian education as originally intended. ${ }^{30}$

The doctrines of the Colonial Reformers may well have had a impact on education in the Empire, but land disposal was not the only factor in guiding the Colonial Office approach to school funding. Frugality, accountability, and self-sufficiency were dictates of British attitudes before the advent of Goderich as Secretary of State (even in land disposal a policy trend away from grants and towards sales was discernible before his time). ${ }^{31}$ Bathurst was certainly mindful of such principles in admonishing Govemor Darling in New South Wales for offering a substantial sum of colonial treasury money to the Church and Schools Corporation in 1825 without authority from London. ${ }^{32}$ Goderich's immediate predecessor, Sir George Murray, had also raised an alarm over the funding of education, signalling displeasure over plans to establish what ultimately became King's College in Upper Canada. The colonial governor was reprimanded for incurring expenses and engaging a teacher without prior approval, a line which Goderich followed in informing Sir John Colborne that he was "not at liberty to increase in the smallest degree" the expense of the establishment without reference to the Secretary of State. ${ }^{33}$ What lay behind Murray's rebuke was the overriding concern about local extravagance, a tendency in the colonies, as he saw it, to embark on schemes too expensive for the means of the particular province. For King's College, he urged a modest beginning tailored to the current needs of the colony and expanding only in response to subsequent increases in local population and wealth. ${ }^{34}$ When religious restrictions had led to the rival existence of two colleges and resistance to their amalgamation in Nova Scotia, the contention that this was an extravagance dictated the Colonial Office role as much as the concern to remove the religious tests for entry. ${ }^{35}$

The Australian situation on higher education, although different from that of North American colonies, still provides some test of the struggle between priorities within the Colonial Office approach to schooling in the Empire. Still dominated by the convict presence, still less populous, and still lacking that substantial middle-class citizenry characterizing the drive in the Canadas for institutions of advanced learning, even the senior Australian colony of New South Wales seemed in the 1830 s relatively infertile soil for the establishment of 
colleges in the North American style. Nevertheless, the changing demographic condition had led denominational leaders and other prominent colonists to press for grammar schools. Murray would not countenance an institution which would award scholarships to the less affluent-- to colonial youth, as described by Governor Darling, of parents "whose past services may appear deserving of this encouragement." Instead, however, he would support the notion of a grammar school for the benefit of the "Upper Classes of Society in the Colony"-provided that it could be established without public expense beyond furnishing moderate salaries to the masters and a building for accommodating the scholars. ${ }^{36}$ But when such grammar schools had begun to operate, the limits of assistance were firmly drawn. Hence in 1835, the Colonial Office was clearly signalling that the King's School at Parramatta, outside Sydney, was patronized by that class of people who could not very well claim education at the public expense and that it should anticipate the eventual withdrawal of public funds. ${ }^{37}$

Since education was seen to be intertwined with the diffusion of religion, it was inevitable that the Colonial Office should take a position on what kind of religion it should support through assistance to education. Upholding Protestant principles in Australian and North American colonies with substantial Roman Catholic minorities produced problems in matters of schooling; in largely Catholic Lower Canada the difficulty was of course very pronounced. Bathurst had sympathized with the objections of Catholics to having their children educated by Protestant teachers and had commended the idea of teaching general religion, as opposed to denominational instruction, in public schools. But he rejected the notion of a separate school system for the Catholics in the province, or any such measure as "might add to the independent power of that Church." Funding they might have for Catholic schools and Catholic teachers, but the appointment of those teachers must be under the control of the Crown. ${ }^{38}$ Sympathy for the purposes of Catholic higher education was similarly laced with a nervousness about Catholic separatism; hence an application in 1829 for a Catholic seminary at St. Hyacinthe was rejected and countered with a college at Montreal to accommodate both Protestants and Catholics by imposing no religious tests for entry. ${ }^{39}$ The question of the Catholic institution and its incorporation opened up the problem of papal authority and its incompatibility with the Elizabethan Act of Supremacy. The consequence, in spite of Stephen's regret, was the disallowance of the provincial act (and a similar one in 1833 incorporating the Catholic St. Andrews College in Prince Edward Island). ${ }^{40}$ It was one thing for the Colonial Office to curb divergent religious control of education, but it was another, especially in an age of policy change on religion (signalled in Britain by the Catholic Relief Act of 1829), for it to countenance other forms of educational disability. Thus in 1837 it found itself strenuously resisting Strachan's contention that the terms of the McGill legacy to the Montreal college had stipulated that the institution should be "essentially Protestant."

For the other colonies, especially in North America, it was a question of dealing with the sensitivities of the various Protestant sects. So vexed had 
competing denominational claims become that it was no longer possible for successive Secretaries of State to confirm the Church of England in its favoured position as Bathurst had done in the second and third decades of the century. Presumably in accord with the firm views of Under-Secretary Stephen on the matter, both Goderich in 1832 and Glenelg five years later conceded the need to diminish privilege with respect to the clergy reserves: the relative strength of the various Protestant groups meant that it was not expedient to promote Church of England interests to the exclusion of others; no system founded on such principles would attain the objective of extending the system of Christian education to all. ${ }^{42}$ The arrangement which impressed Glenelg so much was that provided in Australia, that is, a combination of state support and voluntary effort-ine "half-and-half" system of Governor Bourke of New South Wales of matching grants for schooling to each denomination. Glenelg was not to know that the scheme would be virtually abandoned within a year; what mattered was the principle of using proceeds from the sale of clergy reserves towards some system of public schooling. ${ }^{43}$ The Australian scheme, to which he had given his blessing in 1835 , seemed to him to have that other special virtue which he believed to have characterized the plan of National Education recently adopted in Ireland. That was a system of schooling which offered only general Christianity in the curriculum and relegated denominational doctrines to special times set aside for adherents of the respective church groups. ${ }^{44}$ Greatly disappointed that Broughton (now Bishop) had led a stormy opposition to the scheme, he offered to Bourke his reiterated view on religious exclusiveness in colonial education:

To a continuance indeed in a Colony such as New South Wales of exclusive support to the members of one Church whether for the maintenance of religious worship or for education I conceive that the strongest objections exist, and I have not the slightest reason to doubt the accuracy of the opinion which you have on a former occasion expressed as to the desire on the part of the Colonists for a more liberal and comprehensive system of Public Funds devoted to these purposes. ${ }^{45}$

The stance taken on the matter of the established church was brought most clearly into focus when applied to higher education. In the various North American colonies the Colonial Office had been enthusiastic in facilitating the establishment of colleges, usually with some funding and through securing the granting of a royal charter. What was now causing the British government regret, even well before the 1830 s, was the restrictive nature of some of these charters. The solution proceeded smoothly enough in New Brunswick in 1824, when Bathurst had merely to respond to a request by the Governors and Trustees of the college to dispense with the requirement that matriculating students should subscribe to the thirty-nine articles of faith of the Church of England, not without adding, however, that the concession to college entrants was not also to be granted on taking a degree. ${ }^{46}$ The same type of restriction was obstructing the much- 
needed merger of the two colleges in Nova Scotia, the exclusively Anglican and non-viable King's College at Windsor, and the non-restrictive Dalhousie College at Halifax. A further dimension to the denominational problems in education in that colony was the struggle to gain public funding for Pictou Academy, a Presbyterian institution. This was an issue which found the two branches of the legislature in conflict and the Colonial Secretary in Britain fearful of its consequences for religious and political harmony in Nova Scotia. ${ }^{47}$

In Upper Canada, the Colonial Office had to apply pressure on college authorities to ease religious restrictions. By 1831 , Goderich had reached a state of anxiety over the lack of progress in settling the issue of the constitution of King's College at York. In a province where the Anglicans were in a minority and other denominations seething with anger over the exclusive entry conditions for the college, its corporation had chosen not to heed British House of Commons sentiment in favour of modifying the restrictive clause of the college charter. ${ }^{48}$ The principal concern of the Secretary of State was not only to mollify colonial opinion, important enough in itself, since he recognized that the dispute was amongst the most important issues with which the Office had been asked to deal. ${ }^{49}$ The future of the Anglican Church itself was also at issue, for Goderich saw more clearly than its supporters in the province how continued resistance to change over King's College would increase local animosities to the church. But it was the established church in England and capitulation to denominational equality could not be total. The British government might recommend surrender of the college charter to ease entry conditions, but it would insist on the establishment at King's of a Divinity Professor of the Church of England. ${ }^{50}$ This stance had changed little by the time Stanley had acceded to office, when, in 1845 , he objected to legislation affecting the charter of the New Brunswick college on the grounds that some of the changes proposed were highly offensive to adherents of the Church of England "and that the Class so offended are precisely those for whose more especial advantage the College was originally founded." 51 In a private addendum to his dispatch of 2 November 1831, Goderich had revealed to the governor of Upper Canada how far he was prepared to go in quest of a resolution to the impasse. Should members of the college corporation remain intransigent, the government might feel obliged to enlarge the grants to swamp Church of England membership in government of the college. Yet it was clearly repugnant to have to take such action; not only would this be a desperate last resort directed at the church, but it was obviously calculated as a message to be passed on to the corporation members warning them of the consequences of a contest with the Crown. ${ }^{52}$ Fifteen years later another Secretary of State for the Colonies, one W.E. Gladstone, was pondering the same matter and displaying a similar reluctance to force the pace by permitting legislation to alter the college constitution or to appropriate its funds. ${ }^{53}$

Some of the hesitancy of the Colonial Office to resolve matters of religious and educational dispute derived from a solicitude not so much for church as for governmental relations with the colonies themselves. When occasions arose for 
British official reactions to dissension both over the clergy reserves and access to higher education, the response in these questions, as undoubtedly in a whole range of colonial affairs, was generally dictated by two considerations. One was the clear affirmation of support for the principle of parliamentary representativeness and the other a considerable care to avoid wherever possible interference in issues of local concern. In dealing in 1835 with a proposal by Governor Bourke to introduce into New South Wales a system of undenominational general schooling but with provision for separate religious instruction, Glenelg gave his enthusiastic approval to what he regarded as a very significant plan, but was happy enough to leave the details of the scheme to the legislative role of the Govemor and his appointed Council. ${ }^{54}$ Here was indication of preparedness to allow a vexed matter of great moment to be resolved within the constitutional framework and by those on the spot who presumably appreciated the local circumstances of the time. As previously indicated, no Australian colony was to gain an elected legislature until 1842 but in North America there was already in place the familiar British system of bicameral parliaments. In this situation the two considerations of Colonial Office respect for parliamentary representativeness and avoidance of marked intrusion into matters of local as against imperial concern were often not mutually compatible. This was clearly the case in the clergy reserves question in Upper Canada when in 1835 the Legislative Council of the colony rejected a bill for the sale of the land as a means of funding public education. The Colonial Office believed that it was proper for the House of Assembly, as the popularly constituted chamber, to be in control of the sale of land. But it rejected the idea that the British Parliament should make a decision on the future appropriation of those lands.

Parliamentary legislation on any subject of exclusively internal concern, in any British colony possessing a representative assembly, is, as a general rule, unconstitutional. It is a right of which the exercise is reserved for extreme cases, in which necessity at once creates and justifies the exception. ${ }^{55}$

In a similar case of confrontation between parliamentary chambers over King's College in the province, the Colonial Office sympathies lay with the House representative of the popular will. But just as Goderich in 1831 wished to avoid interference in local affairs on the matter, so Glenelg in 1835 would do no more than offer British mediation if the two Houses remained deadlocked on amending the college charter. ${ }^{56}$ This was also not unlike the situation in Nova Scotia where the Legislative Council placed obstructive conditions on the Assembly's efforts to give financial assistance to Pictou Academy. Goderich strongly supported the Assembly's stance but acted merely by urging conciliation under the direction of the governor. ${ }^{57}$

These two principles - sympathy for the representative branch of the legislature and non-interference in local matters-were not without qualification at 
times. In a later period, the King's College dispute in New Brunswick was to find Lord John Russell initially suggesting that the process of modifying the college charter should bypass the Assembly (for fear the matter would not be settled) and be resolved directly between the college council, the governor, and the Crown. When the governor subsequently misconstrued his instructions and brought the matter before the House of Assembly, Russell relented with the admission that there were, after all, advantages in securing popular endorsement of what was a liberal proposal. ${ }^{58}$ On the question of non-intervention, exceptions were made to suit the occasion. When the Legislative Council of Upper Canada blocked an Assembly bill for a loan to the Methodist college in 1837, the Colonial Office branded the action as illiberal and instructed the govemor to counter it by making a loan out of territorial revenue. ${ }^{59}$ The threat of the purse strings could aiso be used in more negative ways. Goderich, in high dudgeon over the Reverend J.D. Lang's public attack on the Church of England in New South Wales, made it clear that had he known earlier of such "misconduct," a grant approved in 1831 for Lang's Presbyterian academy would have been forfeited. ${ }^{60}$ (In the case of Nova Scotia, when the trend of negotiations on amalgamation of the two colleges seemed destined to displease the colonial Legislative Assembly, the British response was to exert pressure on the colleges by suggesting that they might get no further grants of money.) ${ }^{61}$ This tactic of purse strings persuasion was again employed in 1835 in Upper Canada, with Glenelg in alliance with the Assembly, both withholding financial grants to King's College govemors in order to overcome their resistance to maintaining religious restrictions on entry to the college. $^{62}$ In the Nova Scotia case of efforts to secure a merger of the two colleges, the Colonial Office, in a private communication to the governor, spelled out contingency plans of legal proceedings and legislative action by the Assembly should the governors of King's College continue to resist surrendering the charter. ${ }^{63}$ A device more commonly employed in various other matters, as well as in education, was of course the withholding of royal assent to colonial legislation. Just as Stanley threatened to advise such withholding over the New Brunswick college problem in 1845, so had Russell secured rejection of the 1839 Nova Scotian plan to divide up the school lands in that colony. ${ }^{64}$

From the totality of such issues and incidents there emerges a sense of Colonial Office policy on education, clear and largely consistent. That consistency appears to have prevailed over considerations such as party political affiliation and the rapid succession of Secretaries of State for the colonies. The work of a noted authority on British politics of the era serves as a caution against assuming too much of a difference between Whigs and Tories on the matters surveyed in this paper. ${ }^{65}$ Admittedly, the Tories have largely been identified with the interests of the established church and it is true that the Whig Ministry's 1839 education measure in Britain aimed to equalize funding between the rival Anglican and Dissenting education societies. But to postulate a Whig-Tory division based on the politics of religion is rather too facile. On the one hand, Robert Peel's Tory administration of 1834 did discuss issues of concession to 
Dissenters; on the other hand, many leading Whigs were Anglican, there were limits to Whig -Dissenter affinity, and the party was clearly divided on weakening the established Church, as demonstrated over the proposed appropriation of property of the Church in Ireland. ${ }^{66}$

This qualifying of political differences spills over into the colonial area. In spite of the trend of policy over the clergy reserves, the Whig Colonial Secretary, Glenelg, openly proclaimed in Parliament his anxiety as an Anglican to support that church, while Sir George Murray, a Tory predecessor, more than once attacked the notion of denominational exclusiveness in education with respect to clergy reserves and restriction on college entry in North America. ${ }^{67}$ The narrowing of differences is also seen on the question of funding the Society for Propagation of the Gospel, virtually a Church of England agent in the colonies. When in 1830 the Whig opposition sought to cut its annual vote, Murray conceded that the Church was enjoying disproportionate support, especially, for example, in Nova Scotia and Prince Edward Island; but he took no action to rectify the situation. In the following year the succeeding Whig Ministry demurred at taking swift action to cut SPG funding. ${ }^{68}$

It should be noted that the Whigs were in office for most of the 1830 s, the decade in which much of the concerns of this paper was concentrated. In any case, parliamentary records offer little to suggest fundamental differences between the parties on colonial education, whoever held power. Where Parliament addressed colonial matters, it was notably preoccupied first with slavery and then with the Canadian Rebellion. Attention to most matters of education in the Empire resided in the bureaucracy; indeed it has been observed that (from the time of Bathurst) the Colonial Office was the first government department in which the political head devolved much of the decisions on the permanent officials. ${ }^{69}$ There appears to have been little difference of opinion on education between the political and administrative heads of the Office. James Stephen, who dominated in that era of the department's history, certainly had some difficulties of relationship with some of his political masters, notably Stanley. There was a different view taken on the legalities of colonial legislation to override the charter for the New Brunswick college in 1840, with Stephen disagreeing with both Stanley and Lord John Russell. ${ }^{70}$ But there is also a strong suggestion of similarity of attitude on the general issue of education in the colonies. As Knaplund has indicated, Stephen became an advocate of denominational equality; ${ }^{71}$ in their communications with the various governors, the Colonial Secretaries upheld that advocacy in the field of education.

Thus it can reasonably be concluded that a continuity of the Colonial Office view of education prevailed in the period under examination. It supported, indeed championed, the contemporary notion that education was synonymous with religion and was a vital instrument in inculcating appropriate social and cultural values amongst colonial youth. But that principle had also to be pursued within the context of local sectional rivalries, and harmony within the respective colonies was an even more overriding concern for British governments of the 
day. In advancing educational development and responding to educational problems, successive political incumbents of the Colonial Office followed a line which was influenced by several important considerations. One was the reality of Imperial financial limits to educational investment, not discovered but certainly re-affirmed through the influence of the colonial reform thrust. Another was a keen appreciation of contrasting circumstances between the respective colonies, ranging from obvious demographic to more subtle legal differences arising in the settlement of disputed claims; hence differences in response to situations from colony to colony did not in itself constitute inconsistency. Similarly, pressure exerted at times on local bodies to secure educational goals did not necessarily mean a concerted departure from the general respect for constitutional arrangements, especially those providing for some form of expressing the popular will through representative forms of government. Above all, there had developed a firm policy regarding the position of the Church of England. In an age of reform in Britain and changing denominational demography in the colonies, its exclusive position in education was not being maintained. But sensitivity to its links with the monarchy meant that, in schooling as well as in religion, total decimation of Anglicanism could not be permitted. What the Colonial Office came to favour and press vigorously was the establishment of extensive educational systems in the North American and Australian colonies without special favour to any denomination. What it also came to understand in the $1830 \mathrm{~s}$, with regret, was that for the moment those systems could not be undenominational.

\section{NOTES}

Abbreviations

CO Colonial Office Files, Public Record Office, London.

HRA Historical Records of Australia

1. Helen Taft Manning, The British Colonial Government After the American Revolution 1782.1820 (Hamden: Archon Books, 1966).

2. Paul Knaplund, James Stephen and the British Colonial System 1813-1847 (Madison: Universily of Wisconsin Press, 1953).

3. W.P. Morrell, British Colonial Policy in the Age of Peel and Russell (London: Frank Cass \& Co., 1966).

4. D.M. Young, The Colonial Office in the Early Nineteenth Century (London: Longmans, 1961).

5. John Marning Ward, Colonial Self-Government : The British Experience 1759-1856 (London: Macmillan, 1976).

6. Knaplund, James Stephen, 140.

7. Donald Wilson et al., eds., Canadian Education: A History (Scarborough, Ont.: Prentice Hall, 1970); A.G. Austin, Australian Education 1788-1900: Church, State and Public Education in Colonial Australia (Melbourne: Pitman, 1961).

8. Manning, British Colonial Government, 86.

9. Knaplund, James Stephen; see also Ward, Colonial Self-Government. 
10. Manning, British Colonial Government, 88; Knaplund, James Stephen, 154-57.

11. Manning, British Colonial Government, 90.

12. Young, The Colonial Office, 260.

13. Bathurst to Bigge, 30 Jan. 1819, HRA 1, X, 10.

14. Bathurst to Douglas Smith, 18 Mar. 1815, CO 227/7; Bathurst to Macquarie, 20 Oct., HRA 1, X, 204.

15. Wilson, Canadian Education, 200.

16. Ibid., 196.

17. Austin, Australian Education, 11.

18. Bathurst to Maitland, 6May 1820, British Sessional Papers, House of Commons 32, $1840,2$.

19. Glenelg to Gosford, 7 Sept. 1837, CO 43/33.

20. Ibid.

21. Bathurst to Brisbane, 1 Jan. 1825, HRA 1, XI, 451.

22. Glenelg to Bourke, 11 Apr, 1837,82, HRA 1, XVII, 207.8.

23. Geoffrey to Arthur, 29 Dec. 1837, CO 43/47.

24. Glenelg to Harvey, 25 Aug. 1837, CO 189/15.

25. Russell to Campbell, 23 Sept. 1839, CO 218/32.

26. Glenelg to Fitzroy, 3 Dec. 1837, CO 227/8.

27. Russell to Fitzroy, 24 Sept. 1840, CO 227/8.

28. Austin, Australian Education, 25-26.

29. Goderich to Colborne, 21 Nov. 1831, British Sessional Papers 32, 1840, 31.

30. Aberdeen to Campbell, 23 Mar. 1835, CO 1189/14.

31. June Philipp, "Wakefieldian Influence and New South Wales 1829.1832," Historical Studies (Australia) IX, 33 (1959-61): 174-75.

32. Bathurst to Darling, 6 Oct. $1825, \mathrm{CO} 202 / 15$.

33. Murray to Colbome, 1 Sept. 1829, CO 43/4; Goderich to Colbome, 20 Dec. 1830 , $\mathrm{CO} 43 / 43$.

34. Murray to Colborne, 1 Sept. 1829, CO 43/42; Murray to Colborne, 18 Mar. 1830 , $\mathrm{CO} 43 / 43$.

35. Murray to Maitland, 31 Aug. $1829, \mathrm{CO} 218 / 29$.

36. Murray to Darling, 12 June $1830, \mathrm{CO} 202 / 25$.

37. Glenelg to Bourke, 30 Nov. 1835, CO 202/32.

38. Bathurst to Dalhousie, 15 Dec. 1824, CO 43/25.

39. Murray to Kempt, 3 Sept. 1829, CO 43/27; Murray to Kempt, 27 Apr. 1830, CO $43 / 28$.

40. Knaplund, James Stephen, 144-45.

41. Glenelg to Gosford, 31 Jan. 1837, CO 43/32.

42. Goderich to Colbome, 5 Apr. 1832, British Sessional Papers 32, 1840, 38; Glenelg to Arthur, 15 Jan., 7 Feb. 1839, CO 43/48.

43. Glenelg to Arthur, 26 Dec. 1837, CO 43/47.

44. Glenelg to Bourke, 30 Nov. 1835, CO 202/32.

45. Glenelg to Bourke, 27 Feb. 1837, HRA 1, XVII, 696.

46. Bathurst to Douglas, 19 May 1824, CO $189 / 12$.

47. Goderich to Maitland, 20 July $1831, \mathrm{CO} 218 / 30$.

48. See, for example, comments in Parliamentary Debates (Great Britain), 3rd Series, $8,1831,779$.

49. Goderich to Colborne, 2 Nov. 1831, CO $43 / 43$.

50. Ibid. 
51. Stanley to Colebrooke, 12 Nov, $1845,189 / 17$.

52. Goderich to Colborne, Private Attachment, 2 Nov. 1831, CO 43/43.

53. Gladstone to Cathcart, 3 Feb. 1846, CO $43 / 146$.

54. Glenelg to Bourke, 30 Nov. $1835, \mathrm{CO} 202 / 32$

55. Glenelg to Head, 5 Dec. 1835, British Sessional Papers 32, 1840, 58.

56. Goderich to Colbome, 2 Nov. 1831, CO 43/43; Glenelg to Colborne, 17 June 1835 , CO 43/44.

57. Goderich to Maitland, 20 July 1831, CO 218/30.

58. Russell to Harvey, 3 Nov. 1840; Russell to Colebrooke, 16 May 1841, CO 189/16.

59. Glenelg to Head, 28 Apr. 1837, CO 43/46.

60. Goderich to Bourke, 3 Apt. 1832, HRA I, XVI, 590.

61. Goderich to Maitland, 2 Aug. $1832, \mathrm{CO} 218 / 31$.

62. Glenelg to Campbell, 4 June $1835, \mathrm{CO} 218 / 31$.

63. Grant to Campbell, 30 Apr. 1835, ibid.

64. Stanley to Colebrooke, 3 Nov. 1845, CO 189/17; Russell to Campbell, 23 Sept. 1839 , $\mathrm{CO} 218 / 32$.

65. Norman Gash, Reaction and Reconstruction in English Politics 1832-1852 (Oxford: Clarendon, 1965).

66. Ibid., 70, 73, 76, 81 .

67. Parliamentary Debates (Great Britain), 3rd Series, 8, 1831, 779; 24, 1834, 1089; 41, $1838,725$.

68. Parliamentary Debates (Great Britain), 2nd Series, 25, 1830, 341-43; 3rd Series, 5 , 1831, 295-96.

69. Norman Gash, Aristocracy and the People: Britain 1815-1865 (London: Edward Amold, 1979), 53.

70. Knaplund, James Stephen, 154-55.

71. Ibid., chap. 6. 